\title{
ELECTION OBSERVATION AND MONITORING IN BOTSWANA
}

\author{
David Sebudubudu
}
Dr David Sebudubudu is a senior lecturer in the Department of Political and Administrative Studies, University of Botswana and a member of the Democracy Research Project (DRP)
of the University of Botswana P/Bag UB 00705, Gaborone, Botswana
Tel: +267 355 2732; Fax: +267 3170706
e-mail: sebudubu@mopipi.ub.bw

\begin{abstract}
In an attempt to address the concerns of opposition parties, election observation and monitoring have in recent years become part of the electoral process in Botswana. This paper examines their role in Botswana's electoral process. It argues that election observation and monitoring have promoted transparency and accountability as well as public confidence in the credibility of the Botswana electoral process, especially in recent years. Moreover, they are a source of legitimacy and stability. The paper concludes that it is the emergence of democratic regimes in the region that in part has attracted observers to Botswana's elections despite the fact that its elections have generally been free and peaceful and have involved no major disputes.
\end{abstract}

\section{INTRODUCTION}

Botswana is one of the few countries in Africa to have maintained multiparty democracy, with elections held every five years - the most recent in 2004. With the exception of a few controversies, all nine multiparty elections held since independence have been generally peaceful. Opposition parties are free to contest every election (parliamentary and local) but they remain largely weak organisationally. They are also divided because they do not contest elections as a united force and thus split the opposition vote. As a result, Botswana's regular elections have not led to a change of government. The ruling Botswana Democratic Party (BDP) has won all the elections without facing any serious challenge from 
the opposition parties. This has made Botswana's elections generally uninteresting. Mauritius, which is almost as old as Botswana, has a more functional liberal system and changes in government have taken place smoothly. Senegal went the same route, with the election of the Abdoulaye Wade Government in 2001. Nevertheless, non-violent as well as successive multiparty elections have earned Botswana an international reputation as a stable and peaceful democracy free of the electoral disputes characteristic of so many African countries.

Disputes are a common feature of African elections and frequently threaten the stability of the political system. Examples are those of Lesotho, where, in 1998 the opposition rejected the electoral outcome and resorted to civil disobedience. Zimbabwe, too, is faced with political and economic instability following a disputed presidential election in 2002 that was marred by fraud and irregularities. The incumbent, President Robert Mugabe, won the 2002 election, a result which was rejected by the opposition Movement for Democratic Change (MDC) and its leader, Morgan Tsvangirai. The dispute has plunged the country into a political crisis which has led to an economic crisis with spill over effects on neighbouring countries, especially Botswana and South Africa. Botswana has not yet experienced electoral conflicts of this nature, which endanger the political establishment. Yet allegations by the opposition of electoral cheating are common. It is in this context that the paper analyses the role played in Botswana's electoral system by election observation and monitoring. The object of the paper is to demonstrate the impact of election observation and monitoring on transparency and accountability and thus the credibility and integrity of the electoral process.

\section{ELECTION OBSERVATION AND MONITORING}

EISA and the Electoral Commissions Forum (ECF), two of the organisations that have been actively involved in election observation in recent years, have declared that 'election monitoring and observation have become an integral part of the electoral process in SADC countries, with most accepting monitors/observers from international, regional and national organizations. Such monitors / observers have come to play an important role in enhancing the transparency and credibility of elections and the acceptance of results' (EISA / ECF 2004, p 30). Those countries that have not yet accepted observers/monitors are under pressure to do so.

Election observation and monitoring have become highly contentious issues in recent years, especially with the linking of political reform to economic aid. Most donor organisations and governments have become interested in the reports of election observers and monitors because they are considered the most important ways of judging whether elections were free and fair. A free electoral process 'is one where fundamental human rights and freedoms are respected' 
and a fair one is 'where the playing field is reasonably level and accessible to all electors, parties and candidates' (CommonBorders 2004). Free and fair elections are seen internationally as the basis of good governance and may bestow legitimacy upon the victor. They are also of central importance to sustaining democracy.

Despite the above definition and the existence of widely accepted credible standards of judging an electoral process, what constitutes a free and fair election remains an issue of controversy. This is especially the case when observer groups issue conflicting reports, as they did in Zimbabwe in 2002. Zimbabwe's presidential election was unfair and fraudulent, and the fact that President Robert Mugabe and his party claim differently does not change the judgement.

Bruce George, President of the Parliamentary Assembly of the Organisation for Security and Co-operation in Europe (OSCE), which had 400 observers in Russia during that country's election in 2003, noted that 'our main impression of the overall process was ... one of regression in the democratisation of that country' as it was 'overwhelmingly distorted' (BBC News, 8 December 2003). Similarly, in October 2004 the OSCE observer team condemned the elections and referendum vote in Belarus as having fallen 'significantly short of international standards', thus failing 'to ensure the fundamental conditions necessary for the will of the people to serve as a basis for authority of government' (BBC News, 18 October 2004).

Similarly, in Botswana the advantages of being in office and having access to state resources not only distort election results they give the BDP an edge over other parties. There is also reluctance or inability on the part of the Independent Electoral Commission (IEC) to control campaign spending.

Although election observation and monitoring are intertwined, they also quite distinct. Otlhogile (1994, p 294) defines election observation as 'an attempt by the international community at closely overseeing [a decision-making process such as an election], in order to ensure that every eligible member of that particular nation is afforded an opportunity ... to participate in the decision making in their country, and that the wishes of the majority determine the outcome'. As Otlhogile rightly observed, the purpose of such an exercise is to authenticate elections and re-establish confidence among political contenders.

According to Harris (1997, p 27), an election observer 'is not involved directly in the operation of the election process, has no right to demand changes but does have a role in drawing attention to irregularities and publicising their requests for appropriate action to be taken'. An election monitor, on the other hand, 'is not directly involved in the election process and therefore only has the right to demand changes and to publicise the fact that these demands have been made'. As the United Nations (UN) Code of Practice puts it, observation entails: 
the purposeful gathering of information regarding an electoral process, and the making of informed judgements on the conduct of such a process on the basis of the information collected, by persons who are not inherently authorised to intervene in the process, whose involvement in mediation or technical assistance activities [is unofficial and] should not be such as to jeopardise their main observation responsibilities.

Quoted in Harris 1997, p 27

Thus, election observers and monitors are not only central to but have become part and parcel of the electoral process worldwide, especially in emerging or young democracies, as a way of promoting transparency in the electoral process and encouraging free and fair elections. Dugard (1998) noted that openness is an essential element of ensuring confidence in the election process. Election observation and monitoring are important activities that help to strengthen the democratic process and institutions and the value of elections and to instil confidence in an election. Observers and monitors are believed to carry out their tasks on a non-partisan basis and therefore all interested parties generally accept their judgement.

For an election observation to thrive it must be credible in the eyes of all the contesting parties and that credibility stems from a refusal to take sides and from the impartial and fair-minded nature of the observation endeavour. Thus, transparency in the electoral process is of critical importance in ensuring public confidence in the electoral system and recognition of the election outcome (Dundas 1994). For Totemeyer and Kadima (2000, p 4) 'election observation builds citizen confidence in the integrity of the election process, which encourages them to exercise their voting rights'. Similarly, Ramadhani (1999) points out that election observers might persuade cagey citizens as well as suspicious opposition politicians to take part in the electoral process rather than to resort to violence, as was the case in Angola and Mozambique.

In Zambia in 1991 observers calmed down what might have been intense disagreements over electoral rules and regulations by asking for concessions from government and electoral officials on areas of disagreement (National Democratic Institute for International Affairs - NDI 1992). Thus, election observers can perform a constructive function in generating an enabling environment for all parties participating in a general election (Totemeyer and Kadima 2000), adding value to the electoral process and thereby giving it more legitimacy. Moreover, the involvement of observers may also encourage the government to recognise the outcome and therefore step down if it is defeated. Nicaragua in 1990 under President Daniel Ortega and Zambia in 1991 under President Kenneth Kaunda 
are cases in point. In this way, election observers and monitors help to promote stability. As the NDI (1992) noted, international observers may be asked to arbitrate disagreements among contesting political organisations in an attempt to lessen hostilities prior to, throughout, and subsequent to elections. For an election outcome to be acceptable to all interested parties it should not only be seen to be free and fair but should also not be marred by allegations of fraud. Thus, although free and fair elections are not a sufficient condition for democratic consolidation they are central because of 'their ability to jump-start the process of democratisation and boost the morale of prodemocracy forces' (Nevitte \& Canton 1997, p 51). Election observation and monitoring is one way of trying to attain this end.

Previously, journalists, academics and embassy staff observed elections in foreign countries. However, after World War I, political participation in government came to be accepted as a fundamental right and since then election observation has been institutionalised internationally. The United Nations initially took part in election observation in South Korea in 1948 because it was considered essential to monitor elections in countries emerging from dictatorial military regimes or authoritarian communist rule. Since then, election observation has become common and is also used in developed countries (Ramadhani 1999). A number of organisations have become involved in election observation and monitoring because there has been an increasing acceptance of the contribution of international observers to election processes.

Otlhogile (1994) traces the origins of the Commonwealth observation of elections to the 1971 Singapore Declaration, the essence of which was to advance individual freedom in countries that are members of the Commonwealth. In 1989, the Commonwealth adopted another declaration - the Kuala Lumpur Declaration - in which it pledged to promote democratic values in member countries. The Commonwealth proposed in the Kuala Lumpur Declaration 'that one of [its] contributions to strengthening democracy might be the provision of Commonwealth assistance in helping member countries to reinforce their election and other constitutional processes through a facility for mounting observer missions at the request of member governments, and in responding to such requests in other relevant ways' (Otlhogile 1994, p 295). The promise to promote democratic values within the Commonwealth was repeated two years later in Harare (Otlhogile 1994), demonstrating a desire to support and encourage free and fair elections within the Commonwealth.

However, the implementation of this proposition has always been a thorny issue because it relies heavily on the government of the country conducting the election, thus rendering the Commonwealth a weak organisation in the process of election monitoring. 
Similarly, in June 1990, the Conference on Security and Cooperation in Europe, which comprises all European countries, Canada and the United States, embraced a declaration calling on member states to recognise the need to involve international observers in national elections. This was followed by the endorsement of the practice by the UN General Assembly and the Secretary General of the UN in an attempt to boost efficient, regular and indisputable elections (NDI 1992). As Ramadhani (1999, p 104) has observed, the aim of election observation in emerging democracies

is to enhance internal and international credibility of the electoral process. A basic function of international election observation is detecting and, if possible deterring electoral fraud. Election observation has helped to expose fraud in the Philippines in 1986 and in Panama in 1989 [as well as in Zimbabwe in 2002]. At times, apart from publishing electoral fraud, election observation has also contributed to prevent it. Political authorities may abandon election rigging out of fear of being caught by observers. Moreover, election observation may help to hold together shaky electoral processes in new democracies.

Similarly, Kupe (2000) noted that the participation of observers could help to decrease a propensity towards improper practices by over-zealous political parties or government administrators in charge of elections. Dundas (1994) observed that the involvement of observers during voting and at the count can help calm the election environment and is thought to encourage the openness of both the polling and counting of the ballot papers. The NDI (1992) stated that the presence of international observers is intended to create confidence in the process, to discourage electoral irregularities, and to give an account of the impartiality of the elections to the international community. In the view of the former executive secretary (now Specially Elected Member of Parliament) of the BDP, 'observers [international] are so important because they are a stamp of approval in a democratic process, that is whether the electoral outcome is acceptable or not' (Interview, 19 June 2003). Thus, election observation and monitoring are of special importance because 'the presence of observers has a primary focus on promoting an atmosphere of openness and transparency, thus enhancing public confidence in the election processes and their outcomes. [In this way] observer access to voting processes acts as a deterrent to improper practices and attempts at fraud' (Aceproject 2003). This explains why election observation and monitoring have become so important in recent years, especially in countries undergoing political change. Moreover, election observation ensures that the electoral outcome is 
credible internationally in the light of conditions imposed by donors: economic aid has come to be linked to democracy and good governance. Furthermore, taxpayers in donor countries which contribute to the expenses of conducting elections want to know whether their money has been used effectively.

Election observation in established democracies seeks to act as an example to emerging democracies (Ramadhani 1999). Observation is not merely about verifying the fairness of an election but instead, and more crucially, it extends the concept of democratic norms and procedures to thousands of people, thus helping to build and strengthen a culture of democracy (Green-Thompson 2001). It is in this context that election observation and monitoring have come to be accepted as a key part of the democratic process because they seek to promote transparency and accountability - the central tenets of democracy.

Election observer and monitor missions take different forms, depending on the type and size of the organisation involved, the length of time it stays in the country holding the election and the kind of report produced (Ramadhani 1999). Nevertheless, there are certain experienced and credible election observers - the Commonwealth, the European Union, the Jimmy Carter Group - which have greater capacity than others. Generally, election observers observe the administrative arrangements, the preparedness of the electoral authority, the behaviour of election officials, the police, party agents and voters, the sealing of ballot boxes before and after voting, the escorting of boxes to the counting centre, the count and the balancing of votes (The Catholic Justice and Peace Commission $1994 ; 1999 ; 2004)$. Observers are expected to produce a report highlighting any problems noted as well as their recommendations. They are also expected to pronounce on whether the elections were free and fair. Kupe (2000, p 102) has observed that election observers are 'watchdogs working for the electorate and the political parties involved in the elections. It is their business to make sure that elections are conducted properly during the prescribed times and at the designated venues. It is the observer who reports directly or indirectly to the outside world about the fairness, or otherwise, of the election process.'

There are two main types of observer and monitoring groups or organisations - local and international. Local observers, who are normally citizens of the country whose elections are being monitored, have the edge over international observers because they are familiar with the country concerned. However, although local observers promote transparency in the electoral process, they are often treated with suspicion as having a particular agenda and are thus not seen as impartial. On the other hand, international observers 'have added a new dimension to election transparency' (Dundas 1994, p 45). Nevitte \& Canton (1997, p 50) observed that 'public confidence in internationally driven [observation] efforts characteristically hinges on the reputation and legitimacy of the international or 
regional organization involved, and derives in large part from the multinational membership of the observation team in place'. For Camay and Gordon (1999, p 259) 'international observers bring an added credibility to the monitoring and assessment of elections, in that they are able to refer to their experience elsewhere and apply international standards of good practice wherever they go'. This demonstrates beyond doubt that international observers act as a stamp of approval.

The methods of observer groups range from regular short visits through permanent groups to mobile or stationary teams (Ramadhani 1999), but observers face a number of limitations. As Dundas (1994, p 45) notes, 'there are limitations to the extent to which observers generally can impact on the transparency of the system, since they are not in charge of the machinery which runs the election'. The other limitation they face is that 'they have a limited time to see only the final days of the campaign leading up to the polls, and sometimes many leave before the final results are known'. This, in a way, compromises the role of observers in promoting transparency and accountability in the electoral process.

As Botswana is the oldest and most stable democracy in Africa, its democratic system has not yet caught the attention of most international observer organisations and the international media. The country has enjoyed 'peace and tranquillity' for many years and its 'elections have always been successful' (Molomo \& Somolekae nd, p 111). As Elago (1999, p 115) has noted, 'where the political environment in a given country proves stable and peaceful for the local institutions to organise elections, the presence of international observers and monitors has not been a conditional requirement'. Harris (1997, p 28) observes that election observers were initially meant to provide legitimacy where 'a state was emerging from a long period of autocratic rule'. Botswana does not fit into this category. As one senior official of the IEC of Botswana puts it: 'international observers are not yet interested in Botswana elections because there were no incidents of concern' (telephonic interview, 19 June 2003). In the view of the former Executive Secretary of the BDP Botswana's elections have not yet caught the attention of international observers because 'international observers are attracted to elections where there is potential for conflict or where conflict preceded elections' (interview, 19 June 2003). One member of the Botswana National Front (BNF) Central Committee believes that Botswana has not yet attracted the interest of international observers for a combination of reasons. He observes that 'Botswana is unique because it has not yet experienced violence since independence and has not had serious [electoral] disputes and the opposition has always accepted defeat even where they felt cheated. Moreover, Botswana is regarded as a strong adherent of the rule of law' (interview, 25 June 2003). These factors are rarely present in most African countries. The most recent example of a 
country that has slid into political violence is Zimbabwe, following the 2002 presidential election, whose outcome was rejected by the main opposition. As a result there is pressure on the government of Zimbabwe to hold a fresh election because it is internationally perceived as illegitimate. This may contribute to Robert Mugabe's eventual downfall.

These features make Botswana a unique country envied by many on a continent characterised by political turmoil. Making a similar point Molomo \& Somolokae (nd) quote Otlhogile (1994), who notes: 'not all elections are observed. The international community is committed to circumstances; for instance, where there has been an absence of power sharing, or where there have been autocratic or despotic rulers, or the country has gone through turbulent periods in its history, or perhaps accompanied by human rights violations', which is not the case in Botswana.

Election monitoring and observation are common in countries undergoing political transformation from autocratic regimes to multiparty systems because in such countries elections 'often take place in an atmosphere of uncertainty, confusion and concern about the ability of election administrators to deliver an accurate and impartial electoral result'. As the NDI has stated (1992, p 61) 'previously, international observation of elections in Africa had taken place in the context of a transition from colonial rule, as in Zimbabwe in 1980 and in Namibia in 1989, or in the absence of a centrally controlled authority, as in Uganda in 1980'. Zambia, during its 1991 elections, was the first independent African country to ask for the involvement of international observers. Therefore, in such conditions, both local and external election observers 'play an increasingly important role in promoting free and fair elections that can lead to the establishment of accountable, effective governance'.

For Nevitte \& Canton (1997, p 47) transitional democracies interest international observers because 'they not only constitute a litmus test of a regime's devotion to a variety of democratic values and procedural norms, but also provide critical opportunities for voters to weaken or break the grip of authoritarian governments'. In this sense, it can be argued that 'monitors and observers are mostly interested in overseeing an election in suspect areas' (Elago 1999, p 116). Thus, countries undergoing political transition attract international observers because there is a great deal of uncertainty surrounding transitional elections. International observers and monitors in such countries are expected to re-establish the confidence not only among those contesting such an election but also among foreign investors. As Otlhogile (1994, p 294) puts it, 'the country concerned is in the process of reconstructing itself politically and seeks the assistance of the international community. [It] wants to regain its position in the community of nations by allowing international observers to pass judgement that the elections 
were properly conducted.' Thus, for Otlhogile (1994, p 294, quoting Reisman, 1992), 'the purpose of the international observation is to assure the world community that the election meets the minimum requirements of an international standard', that is, the elections were 'free and fair'. This might partly explain why Botswana's democratic system has not yet attracted many foreign observers and monitors - its elections have generally met the internationally acceptable minimum standards. One reason for this may be that the party in power is committed to multiparty democracy, another may be that the ruling party has never faced any serious threat from the opposition, which is in disarray.

Notwithstanding the importance of election monitoring and observation to the promotion of transparency and accountability in the electoral process, a few observations can be made about election observers and monitors. Although their role is widely appreciated and, at times, over emphasised, their judgements have never resulted in new elections being held in any country. The April and December 2003 elections in Nigeria and Russia respectively are cases in point. However, their reports might indirectly prompt people to revolt, resulting in new elections being held. In Georgia recently, for instance, fraudulent elections led to the storming of Parliament and new elections in which the corrupt sitting president was ousted.

\section{ELECTION OBSERVATION AND MONITORING IN BOTSWANA}

Botswana's electoral process is not flawless; its electoral practices have demonstrated certain qualities that are inconsistent with the notion of a free and fair election. Elections have been surrounded by controversy, with opposition parties accusing the ruling BDP of cheating and demanding that the Office of the Supervisor of Elections be removed from that of the president. These demands led to the establishment of the IEC in 1997, following a national referendum. Until that date the president had appointed the supervisor of elections. The IEC is made up of commissioners who are appointed on a part-time basis by the Judicial Service Commission (JSC). The 1999 elections were the first to be conducted by the IEC.

As a result of the controversies surrounding past elections, especially those in 1984 and 1989, a number of organisations, including the Catholic Justice and Peace Commission (CJPC) and the Democracy Research Project (DRP) of the University of Botswana, decided to observe Botswana's elections. According to the CJPC (1994, p 3), its decision to observe the 1994 general elections

came in the background of a controversy that surrounded the past elections. The 1984 and 1989 elections particularly, could rightly be 
rated the most controversial in Botswana's political history. In each of these two elections several petitions seeking to nullify the results were brought before the High court. Although most of the petitions were rejected, often on a technicality, two crucial ones, one in 1984 and another in 1989 relating to the parliamentary elections were upheld by the court and re-elections held in Gaborone South (1984) and Mochudi (1989).

A lack of resources has meant that the activities of the observer organisations are limited to certain selected constituencies. For instance, the CJPC observed elections in 16 constituencies in 1994 and eight in 1999. Similarly, the DRP, a non-partisan multidisciplinary organisation that was established in 1987 and aims to study and monitor democratic processes and institutions in Botswana, observed elections in selected constituencies in 1989, 1994 and 1999. For instance, in 1994 it observed elections in 10 constituencies, but 'even within these constituencies not all polling stations were visited' (DRP 1994, p 3). In 1999 it selected ten of the country's 40 constituencies for observation, sampling a number of polling stations within each (DRP 1999) and concluding that the 1999 elections were free and fair. The elections were peaceful and proceeded smoothly throughout the constituencies where observation was done' (1999, p 16).

The Electoral Commissions Forum (ECF) of the Southern African Development Community (SADC), through its SADC missions, observed the Botswana elections for the first time in 1999 at the invitation of the Botswana IEC. Its observation was limited to Gaborone, Francistown and Lobatse. The ECF, which is comprised of 14 SADC electoral commissions, was initiated in Cape Town, South Africa, in 1998 (Kadima 1999). In its observation and monitoring missions the ECF is guided by the Principles for Election Management, Monitoring and Observation in the SADC Region (PEMMO) developed jointly with EISA. Another SADC structure that observes elections is the SADC Parliamentary Forum (SADC PF), which is an inter-parliamentary organisation of SADC parliaments. It has no powers, is largely supported by donor funds and uses the SADC PF norms and standards for elections in the SADC region in its observation missions. There is also a SADC observer team which observes elections in SADC at the invitation of the member state, in line with the provisions of the Protocol on Politics, Defence and Security Cooperation, which is binding on member states. In addition to this protocol, SADC has its own principles and guidelines governing democratic elections. These are used by SADC observer teams as a reference point but they are not part of the Protocol on Politics, Defence and Security Cooperation and are thus not binding on member states, a factor which makes SADC a weak organisation in terms of election observation and monitoring. 
Unlike those of conventional observer groups, SADC mission's main objective 'is to act as a capacity building resource to the Electoral Authority [of the country concerned]. This means that its role will not, in the first instance, be to assess the correctness of the electoral process in relation to international norms and standards, but rather the development of a constructive and formative relationship which will enable the improvement of electoral processes within the region' (SADC Electoral Observation Missions 2001, p 3). Nevertheless, '...the overall goal of [SADC] missions is to contribute to the establishment and consolidation of democratic ideals and practices within the region' (Nupen 1999, $\mathrm{p}$ 109). Observer groups use certain universal indicators to assess an election. These include, among others, fairness, equality, freedom, universality, secrecy, transparency, and accountability. When assessing or observing an election, SADC observer missions are governed by a code of conduct as well as by a code of practice (SADC Electoral Observation Missions 2001). The ECF concluded that 'the 1999 Botswana election was very peaceful. The ECF observers did not receive any reports of violence or intimidation during the electoral campaign period' (Kadima 1999, p 16).

In 1999 the Botswana IEC also requested an external assessment of its conduct of the 1999 parliamentary and local government elections. Following this invitation, a team of electoral experts from three Commonwealth countries, led by David Zamchiya of Zimbabwe, visited Botswana. The other members of the team were Dinanath Gajadhar of Trinidad \& Tobago and Victor Butler of the United Kingdom. The team, which was funded by the British Department for International Development (DFID), was mandated to examine the electoral laws and regulations, election operations, and public and institutional involvement. The team worked closely with the DRP, which conducted an exit poll in selected constituencies on polling day (Zamchiya 2000). The Zamchiya Report (2000, p 2) noted that 'the IEC felt that an external view would assist the people of Botswana to improve on the electoral delivery system with the benefit of comparative experience from other countries'. In its report, the Commonwealth team not only made some recommendations on how the conduct of elections in Botswana could be improved but observed that 'the 1999 elections [in Botswana] were not marked by high levels of conflict between the parties, and were generally conducted in a manner consistent with a peaceful and democratic society' (Zamchiya 2000, p 3). The reiteration by an international team that Botswana's elections were free and peaceful not only ensures credibility and enhances the country's democratic processes, it also legitimises the whole election process, thus making the electoral outcome internationally acceptable. In this sense, it can be argued that observer reports and missions add value to Botswana's democracy, legitimises its government and deepens its democracy. 
The foregoing evidence shows that although efforts were made by both local and regional observer groups to observe Botswana's elections in recent years, a shortage of resources has made it impossible to do so in all constituencies and at all polling stations. Thus, the elections have largely remained the preserve of the election authority and party agents. Moreover, the evidence documented above shows that election observation and monitoring is a new element of Botswana's democracy. As a result, the literature in this field is scanty. A workshop held in 2000 to evaluate the performance of the IEC in the 1999 elections underscored the role of election observation and monitoring. The workshop noted that

although election monitoring and observation have not historically been an important aspect in Botswana elections, it was a good practice which needed to be maintained. It was agreed [at the workshop] that election observation, particularly by external observers enhances the credibility and transparency of the electoral process, and hence it was an important aspect in delivering free and fair elections. [The workshop] also noted that observers can be helpful to the electoral process and the success of an election

Somolekae \& Lekorwe 2000, p 36

In line with this observation, the 2004 elections - unlike the previous ones attracted a number of observer teams (59 organisations), both domestic and international (Republic of Botswana 2004) and no adverse reports were received, although 'some observers attracted criticism that they came on the eve of election day and as such ... missed out on a lot of things' (Republic of Botswana 2004, p 11). The involvement of election observers underscores the country's dedication to transparency in its electoral process (Republic of Botswana 2004).

One of the organisations that observed the 2004 elections was EISA. Using PEMMO as a tool of assessment, the EISA observation mission concluded that the elections 'were conducted in a peaceful, professional and transparent manner. There were no major legal or political hindrances that could have adversely affected the constitutional right of the citizens of Botswana to freely choose their leaders' (EISA 2005, p 25). Professor Jacqueline Solway of Kent University in Canada, who observed the voting process in the Dutlwe/Tshwaane area, noted that voting was 'free and fair'. However, Solway (2004) observed that 'the fairness of the democratic election process could be enhanced if opposition parties could access more public support and media coverage'. The CJPC $(2004, \mathrm{p} 7)$ also concluded that in the constituencies it observed in 2004 it 'did not come across any sign of organised effort to cheat or change the results of the elections so that they favour one party and disadvantage others. The process was well organised 
and the voters fully and fairly assisted.' Such declarations are a stamp of approval and, by extension, a source of legitimacy and stability. They not only validate Botswana's electoral process but are also important as it is no longer the only democracy in the region. With the emergence of other democracies Botswana should, from time to time, assess the quality of its democracy. Observer reports are one way of helping the country to do so. In this context election monitoring and observation are crucial as they lend credibility and integrity to the electoral process.

\section{CONCLUSION}

Although Botswana has held several multiparty elections since independence, until recently election observers and monitors were not part of the electoral process. One explanation for this is that Botswana's elections have been held in a peaceful atmosphere which international observers have not regarded as suspect. However, Botswana's elections have, in the recent past, attracted the attention of international observers. In part the reason for this is the emergence of democratic regimes in Southern Africa, which have put Botswana's democracy under the spotlight. Before this Botswana was seen as the model of democracy. By inviting international observers Botswana seeks to strengthen its democratic culture even further. Notwithstanding the importance of election monitoring and observation in promoting transparency and accountability in the electoral process, a few observations can be made: their judgement of elections has never resulted in a reelection in any country; although they are expected to be impartial, an element of bias cannot be ruled out; and finally, at best, their opinions only have moral significance.

\section{REFERENCES}

Aceproject. 2003. 'Election Observation: Why Observe Voting Operations Processes?'. www.aceproject.org/main/english/po/poa03/default.htm, 24 June.

BBC News. 2003. ‘Monitors Condemn Russian Election'. In news.bbc.co.uk/2/hi/ Europe/3300483. London, 8 December.

—_. 'Observers Deplore Belarus Vote'. 2004. In news.bbc.co.uk/2/hi/Europe/ 3752930. London, October.

Camay, P \& J A Gordon.1999. The People have Spoken...A Review of the 1999 South African Election. Johannesburg: Co-operative for Research and Education.

Catholic Justice and Peace Commission, The. 1994. Report of the Catholic Justice and Peace Commission on the observation of Botswana's 1994 General Elections. Gaborone: Diocese Gaborone. 
CommonBorders. 2004. 'Elections in Latin America. What Constitutes a Free and Fair Election?'. In www.commonborders.org/free_and_fair.htm, 21 April.

Democracy Research Project (DRP). 1994. A Report on the 1994 Elections. Gaborone: Democracy Research Project.

- 1999. An Evaluation of the Performance of the Independent Electoral Commission (IEC) in Botswana's 1999 Elections. Gaborone: Democracy Research Project. Dugard, J. 1998. 'Current Issues in Election Management'. In C W Dundas (ed). Discussion of Election Issues in Commonwealth Africa. London: Commonwealth Secretariat.

Dundas, C W. 1994. Dimensions of Free and Fair Elections. London: Commonwealth Secretariat.

EISA. 2005. EISA Election Observer Mission: Botswana Parliamentary and Local Government Elections 30 October 2004. Report No 16. Johannesburg: EISA. EISA/Electoral Commissions Forum (ECF). 2004. Principles for Election Management, Monitoring and Observation in the SADC Region. Johannesburg: EISA.

Elago, A N. 1999. 'The Role of Monitors and Observers During Elections: The SADC Experience'. In SADC/EU Conference Proceedings: 'Strengthening and Consolidating Democracy in SADC through the Electoral Process'. Gaborone, 20-22 June.

Green-Thompson, A. 2001. 'Election Observations: Issues and Debates'. In South Africa's Local Government Elections 2000: Evaluation and Prospects. Seminar Report No 12. Johannesburg.

Harris, J. 1997. 'Election Observation with Reference to International Observation Missions'. In NGO Roundtable - Strengthening Democracy through Civil Society. Gaborone, 18-20 August.

Kadima, D. 1999. Botswana Elections Observer Mission Report. The Electoral Commissions Forum of SADC Countries, 16 October.

Kupe, M. 2000. 'Does Election Observation Improve the Confidence of Political Parties and the Public in Election Results?'. In C W Dundas (ed). Rules of Elections in Commonwealth Africa. London: Commonwealth Secretariat.

Molomo, M G \& G Somolekae. nd. 'Sustainable Electoral Democracy in Botswana'. A paper presented to an International IDEA-SADC Conference, 'Towards Sustainable Democratic Institutions in Southern Africa'. In www.idea.int/ideas_work/22_s_africa/elections_5_botswana.htm.

National Democratic Institute for International Affairs. 1992. The October 31, 1991 National Elections in Zambia. Carter Center: Emory University.

Nevitte, N \& S A Canton. 1997. 'The Role of Domestic Observers'. Journal of Democracy 8(3). 
Nupen, D. 1999. 'The Role of Monitors and Observers During Elections: The Electoral Commissions Forum of SADC countries'. In SADC/EU Conference Proceedings, 'Strengthening and Consolidating Democracy in SADC through the Electoral Process', Gaborone 20-22 June.

Otlhogile, B. 1994. 'Observing for Democracy: A Note on the Practices of the Commonwealth Observer Groups'. African Journal of International and Comparative Law, 6(2).

Ramadhani, S L. 1999. 'The Role of Monitors and Observers During Elections'. In SADC/EU Conference Proceedings, 'Strengthening and Consolidating Democracy in SADC through the Electoral Process', Gaborone, 20-22 June. Republic of Botswana. 1966. Constitution of Botswana. Chapter 1. Gaborone: Government Printer.

- 2004. Report to the Minister of Presidential Affairs and Public Administration on the 2004 General Elections. Gaborone: Independent Electoral Commission. SADC Electoral Observation Missions. 2001. 'Terms of Reference'. In EISA. Election Observer Missions: Terms of Reference. Auckland Park: EISA Library.

Solway, J. 2004. Report to IEC. Peterborough, Canada: Trent University.

Somolekae, G \& M Lekorwe. 2000. An Evaluation of the 1999 Elections. Proceedings of a Workshop held on 26-27 June. Gaborone: Independent Electoral Commission Botswana.

—. 1999. Report on Observation of Botswana 1999 General Elections. Gaborone: Diocese Gaborone.

- 2004. Report of the Catholic Justice and Peace Commission on the observation of Botswana's 2004 General Elections. Gaborone: Diocese Gaborone.

Totemeyer, G \& D Kadima. 2000. Handbook for Election Observer Missions. Auckland Park: EISA.

Zamchiya, M D. 2000. Report of a Team of Experts on the Conduct of October 1999 Elections in Botswana, March. 